\title{
Study on Preparation Technology of Enzymatic Peptides of Corbicula Fluminea
}

\author{
Y.L.Yang, L.Zhao*, C.Q.Bai, M.L,Yuan, L.L.Chen, Z.Z.Wu \\ College of Life Science, Jiangxi Science and Technology Normal University, National R\&D Branch Center \\ for Freshwater Fish Processing, Nanchang, 330013 China
}

* Corresponding Author

\begin{abstract}
The preparation technology of enzymatic peptides of Corbicula Fluminea was studied in this paper. Alcalase, Papain, Neutrase and Protamex were used under their own optimum $\mathrm{pH}$ value and temperature, with the same other parameters. The results indicated that Alcalase had the highest degree of hydrolysis (DH). The dosage of enzyme, hydrolysis time, hydrolysis temperature was further investigated. The hydrolysis parameters defined by the orthogonal test. The results showed that the temperature was $50^{\circ} \mathrm{C}$, the dosage of enzyme was $2 \%$, the $\mathrm{pH}$ was 8.5 , the substrate protein concentration was $2 \%$, which the $\mathrm{DH}$ was 26.95.
\end{abstract}

KEYWORDS: Corbicula Fluminea; proteolysis; orthogonal test; polypeptide

\section{GENERAL INTRODUCTION}

In the last decade, the enzymatic hydrolysis of proteins-from animal and plant sources to producing bioactive peptides has attracted much attention [1]. Several studies have reported that peptides from various food sources, in addition to their nutritional properties, exhibited biological activities including antioxidant [2]. The use of enzyme technology could shift the low-cost but high-value protein to a new food source [3]. Proteolytic enzymes are used to digest proteins into two fractions. The insoluble fraction may be used as animal feed and the soluble one, which contains soluble proteins/peptides, may be used as a functional food additive. Protein hydrolysate can be prepared by enzymatic hydrolysis from fish muscle, especially those with low market value. Recently, protein hydrolysates from yellow stripe trevally have been produced successfully using Alcalase (HA) and Flavourzyme (HF) [4]. The nutraceutical and functional food market is one of the fastest growing markets in the world. Fish protein hydrolysates (FPH) possess many desirable properties such as health promoting bioactivities, making them eligible ingredients in nutraceuticals and functional food [5]. Another study reported by Aleman, Gimenez, Montero, and Gomez-Guillen (2011) attempted to prepare the protein hydrolysates from Tuna and Halibut skin gelatins [6]. The objectives of this study were to fractionate soluble and insoluble hydrolysates after the process of enzymatic hydrolysis by commercial proteases. The enzymatic peptide was also characterized regarding their degree of hydrolysis (DH).

\section{MATERIALS AND METHODS}

\subsection{Materials}

Corbicula Fluminea were fished from Poyang Lake (in Jiangxi Province ). Neutrase, protamex and alcalase were purchased from Novozymes Biotech Co., Ltd. Papain were purchased from Nanjing Pombo biological Ltd. Other reagents were analytically pure.

\subsection{Preparation of Corbicula Fluminea extracts}

The fresh Corbicula Fluminea was put in clear water to spit sands two days. The Corbicula Fluminea was washed and the meat was separated manually. The meat was minced using grinder. The mince were soaked in distilled water $(1: 20 \mathrm{w} / \mathrm{v})$ at $48^{\circ} \mathrm{C}, 23 \mathrm{~min}$, 920 watts of ultrasonic power extraction. The supernatant was obtained by centrifugation $(5000 \mathrm{r}$, $20 \mathrm{~min}$ ), and the extracts were spray drying. Dried extracts were placed in seal bag and stored in desiccator before use.

\subsection{Production of protein hydrolysates from Corbicula Fluminea}

$\mathrm{DH}$ is defined as the percentage of free amino groups obtained by the cleavage of a protein, which 
was calculated from the ratio of $\alpha$-amino nitrogen and total nitrogen [7]. During the hydrolysis process, one 10-mL sample was collected at the time needs from each of the hydrolysis conditions. The reaction was heat for $20 \mathrm{~min}$ at $80{ }^{\circ} \mathrm{C}$ to inactivate enzymes as before and added of $10 \mathrm{~mL}$ of $10 \%(\mathrm{w} / \mathrm{v})$ TCA [8]. After resting for $30 \mathrm{~min}$, these samples were centrifuged $(5000 \mathrm{rpm}$ for $20 \mathrm{~min}$ at room temperature) and the protein content was determined with the Kjeldahl method. A factor of 6.25 was used to convert nitrogen to crude protein.

$\mathrm{DH} \%=\left(\frac{10 \% \mathrm{TCA} \text { soluble protein in the sample }}{\text { total protein in the sample }}\right) \times 100$

\section{RESULTS AND DISCUSSIONS}

\subsection{Effect of different enzyme on degree of hydrolysis}

The dried extracts $(5.56 \mathrm{~g})$ samples were resolved in $200 \mathrm{ml}$ distilled water, and adjusted to optimal $\mathrm{pH}$ and temperature for each enzyme. Enzymes were used at the same amount to compare hydrolytic efficiency.

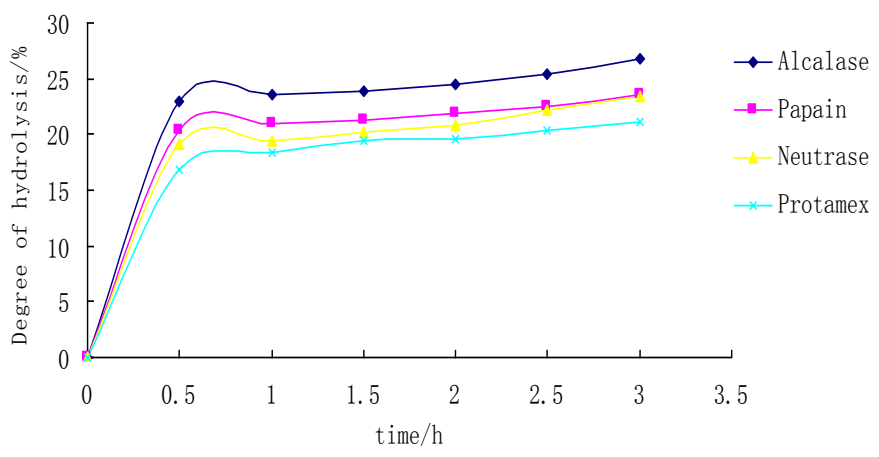

Figure 1. Effect of different enzyme on degree of hydrolysis

The effect of different enzyme on degree of hydrolysis was shown in Fig.1. The hydrolysis of proteins with all proteases was characterized by a high rate of hydrolysis during the initial $30 \mathrm{~min}$. The rates of enzymatic hydrolysis were subsequently decreased, and then the enzymatic reaction reached a steady-state phase. The alcalase proteases were the most efficient, while protamex was the least efficient. Indeed, after 3 hours of hydrolysis, the DH values were $26.84 \%, 23.56 \%, 23.4 \%$ and $21.13 \%$ for hydrolysates prepared with alcalase, papain, neutrase and protamex respectively.

\subsection{Effect of hydrolysis conditions on degree of hydrolysis}

The effect of time on degree of hydrolysis was determined in the condition of the enzyme dosage $2 \%$, the temperature $40^{\circ} \mathrm{C}$, the $\mathrm{pH} 8$ and the substrate protein concentration $1 \%$. The enzymatic reaction reached a steady-state phase after 3 hours of hydrolysis (Fig.2).

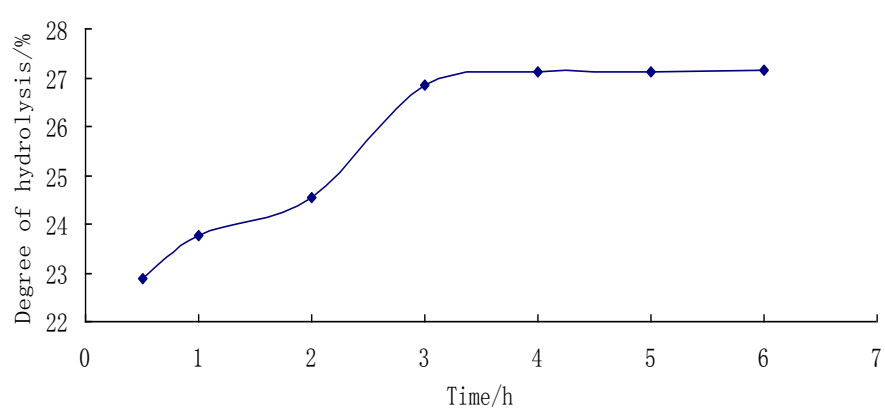

Figure 2. Effect of different the time on degree of hydrolysis

The effect of temperature on degree of hydrolysis was determined in the condition of the enzyme dosage $2 \%$, the time 3 hours, the $\mathrm{pH} 8$ and the substrate protein concentration $1 \%$. When the temperature was $50{ }^{\circ} \mathrm{C}$, the degree of hydrolysis reached maximum (Fig.3), then the degree of hydrolysis decreased with the temperature increasing. May be the high temperature destroyed the enzyme activity.

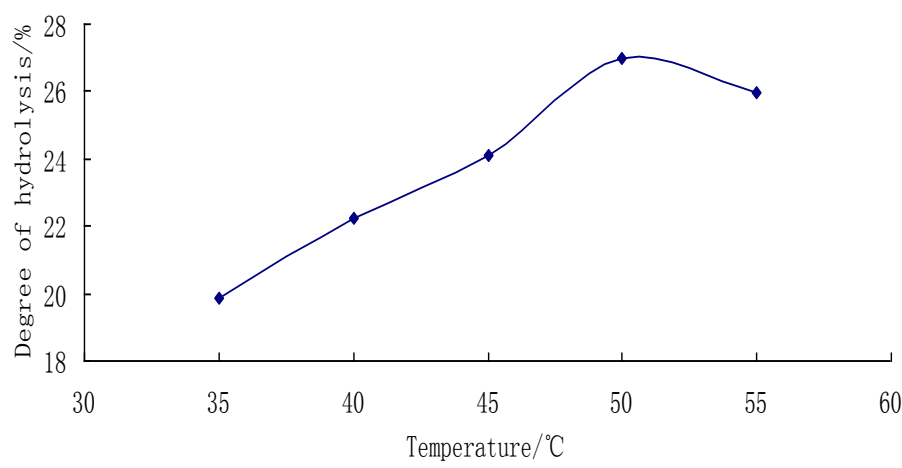

Figure 3. Effect of the temperature on degree of hydrolysis

The effect of enzyme dosage on degree of hydrolysis was determined in the condition of the time 3 hours, the temperature $50^{\circ} \mathrm{C}$, the $\mathrm{pH} 8$ and the substrate protein concentration $1 \%$. The enzymatic reaction reached a steady-state phase with the increase amount of adding enzymes when the addition amount was $2.5 \%$ (Fig.4).

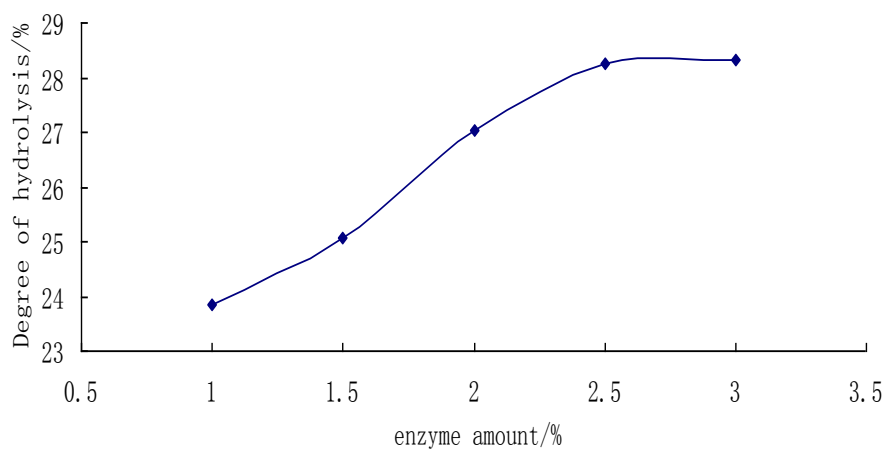

Figure 4. Effect of the enzyme amount on degree of hydrolysis 
The effect of $\mathrm{pH}$ on degree of hydrolysis was determined in the condition of the enzyme dosage $2.5 \%$, the temperature $50^{\circ} \mathrm{C}$, the time 3 hours and the substrate protein concentration $1 \%$. The degree of hydrolysis increased along with the increasing of $\mathrm{pH}$ in range of 7.5-8.5 (Fig.5). Then the hydrolysis degree of decline when the $\mathrm{pH}$ increase.

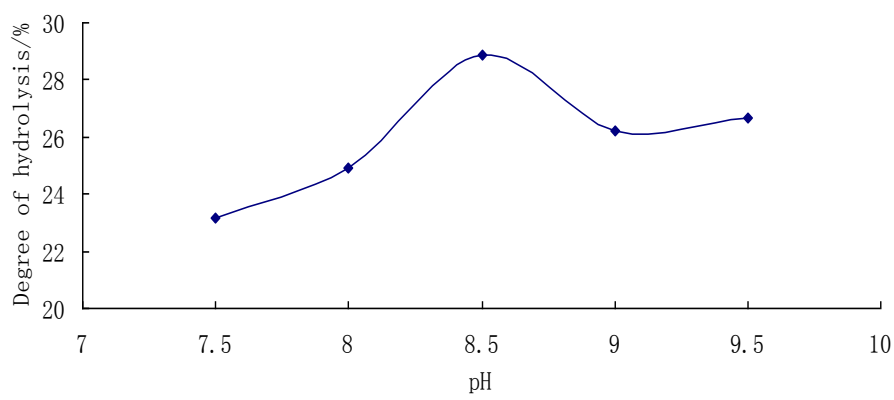

Figure 5. Effect of the $\mathrm{pH}$ on degree of hydrolysis

The effect of the substrate protein concentration on degree of hydrolysis was determined in the condition of the enzyme dosage $2.5 \%$, the temperature $50^{\circ} \mathrm{C}$, the $\mathrm{pH} 8.5$ and the time 3 hours. The degree of hydrolysis increased firstly then decrease, with the substrate concentration increasing (Fig.6). This is due to the substrate concentration increased to a certain degree the competitive inhibition will happen.

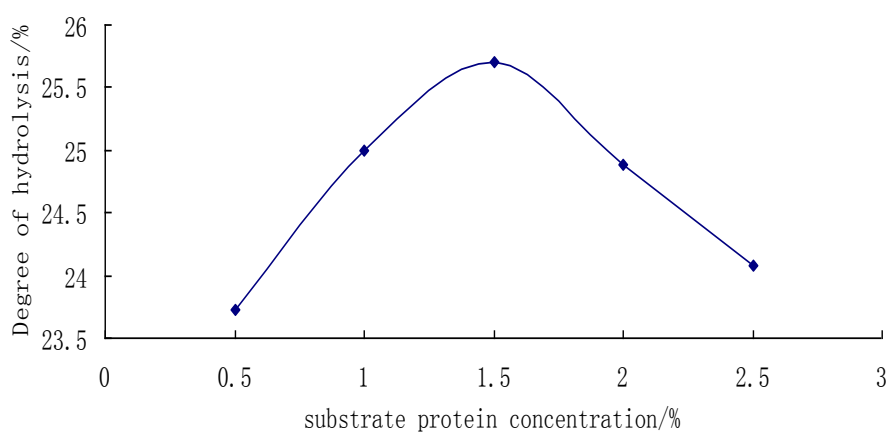

Figure 6. Effect of the substrate protein concentration on degree of hydrolysis

\section{T 3.3 ORTHOGONAL EXPERIMENT RESULTS}

The L9(3)4 Orthogonal test was carried out to optimize the hydrolysis conditions, and nine tests and results were shown in Table 1. According to Table 1, different combinations and different results were given. The primary and secondary factors of impact test results was $\mathrm{A}>\mathrm{C}>\mathrm{D}>\mathrm{B}$. According to the comparison and the results of further experiment, the optimum hydrolysis condition was the combination of $\mathrm{A}_{2} \mathrm{~B}_{1} \mathrm{C}_{2} \mathrm{D}_{3}$, namely the temperature $50{ }^{\circ} \mathrm{C}$, the enzyme amount $2 \%$, the $\mathrm{pH} 8.5$, the substrate protein concentration $2 \%$, which the DH $26.95 \%$.

Table 1 Results of orthogonal experiment

\begin{tabular}{|c|c|c|c|c|c|}
\hline test number & A (temperature) & B (enzyme amount) & $\mathrm{C}(\mathrm{pH})$ & $\begin{array}{c}\mathrm{D} \text { (substrate protein } \\
\text { concentration) }\end{array}$ & $\mathrm{DH} \%$ \\
\hline 1 & $1\left(45^{\circ} \mathrm{C}\right)$ & $1(2 \%)$ & $1(8)$ & $1(1 \%)$ & 22.24 \\
\hline 2 & 1 & $2(2.5 \%)$ & $2(8.5)$ & $2(1.5 \%)$ & 22.04 \\
\hline 3 & 1 & $3(3 \%)$ & $3(9)$ & $3(2 \%)$ & 22.72 \\
\hline 4 & $2\left(50^{\circ} \mathrm{C}\right)$ & 1 & 2 & 3 & 25.37 \\
\hline 5 & 2 & 2 & 3 & 1 & 23.21 \\
\hline 6 & 2 & 3 & 1 & 2 & 23.40 \\
\hline 7 & $3\left(55^{\circ} \mathrm{C}\right)$ & 1 & 3 & 2 & 22.90 \\
\hline 8 & 3 & 2 & 1 & 3 & 24.61 \\
\hline 9 & 3 & 3 & 2 & 1 & 26.65 \\
\hline $\mathrm{K}_{1}$ & 66.99 & 74.16 & 70.26 & 72.09 & \\
\hline $\mathrm{K}_{2}$ & 71.97 & 69.87 & 74.07 & 68.34 & \\
\hline $\mathrm{K}_{3}$ & 71.16 & 72.78 & 68.82 & 72.69 & \\
\hline $\mathrm{k}_{1}$ & 22.33 & 23.50 & 23.42 & 24.03 & \\
\hline $\mathrm{k}_{2}$ & 23.99 & 23.29 & 24.69 & 22.78 & \\
\hline $\mathrm{k}_{3}$ & 24.72 & 24.26 & 22.94 & 24.23 & \\
\hline $\mathrm{R}$ & 2.387 & 0.970 & 1.744 & 1.453 & \\
\hline primary-secondary factors & \multicolumn{5}{|c|}{$\mathrm{A}>\mathrm{C}>\mathrm{D}>\mathrm{B}$} \\
\hline optimal combination & \multicolumn{5}{|c|}{$\mathrm{A}_{2} \mathrm{~B}_{1} \mathrm{C}_{2} \mathrm{D}_{3}$} \\
\hline
\end{tabular}




\section{REFERENCES}

[1] Ruann J. S. de Castro. Helia H. Sato Antioxidant activities and functional properties of soy protein isolate hydrolysates obtained using microbial proteases. International Journal of Food Science and Technology 2014, 49, 317-328

[2] Ktari, N., Jridi, M., Bkhairia, I., Sayari, N., Ben Salah, R., \& Nasri, M. (2012). Functionalities and antioxidant properties of protein hydrolysates from muscle of zebra blenny (Salaria basilisca) obtained with different crude protease extracts. Food Research International, 49, 747756.

[3] Kristinsson HG and Rasco BA, Kinetics of the hydrolysis of Atlantic salmon (Salmo salar) muscle proteins by alkaline proteases and visceral serine protease mixture. Process Biochem 36:131-139 (2000).

[4] Klompong, V., Benjakul, S., Kantachote, D. \& Shahidi, F.
(2007). Antioxidative activity and functional properties of protein hydrolysate of yellow stripe trevally (Selaroides leptolepis) as influenced by the degree of hydrolysis and enzyme type. Food chemistry, 102, 1317-1327.

[5] Harnedy, p. A., \& FitzGerald, R. J. (2012), Bioactive peptides from marine processing waste and shellfish: A review. Journal of Functional Foods, 4(1), 6-24.

[6] Aleman, A., Gimenez, B., Montero, P., \& Gomez-Guillen, M. C. (2011). Antioxidant activity of several marine skin gelatins. LWT-Food Science and Technology, 44, 407-413.

[7] Nilsang, S., Lertsiri, S., Suphantharika, M., Assavanig, A., 2005. Optimization of enzymatic hydrolysis of fish soluble concentrate by commercial proteases. J.Food Eng. 70, 571-578.

[8] Cahú, T.B., Santos, S.D., Mendes, A., 2012. Recovery of protein, chitin, carotenoidsand glycosaminogycansfrom Pacific white shrimp (Litopenaeus vannamei) process waste. Proc. Biochem. 47, 570-577. 